\title{
Lo onettiano en los bordes del realismo mágico
}

\author{
MAXIMILIANO LINARES, UNIVERSIDAD NACIONAL DE ROSARIO, ARGENTINA
}

Fecha de recepción: mayo de 2014

Fecha de aceptación: agosto de 2014

\section{RESUMEN}

Considerando el conjunto de sesenta y siete cartas que el narrador uruguayo Juan Carlos Onetti envía al crítico e historiador del arte argentino Julio. E. Payró entre los años 1937 y 1955 desde Montevideo a Buenos Aires, analizaremos una serie de temas y cuestiones que adquieren una significación primordial en el plano de la poética onettiana. Se torna fundamental entonces indagar en el hecho y el modo en que se produce la recepción por parte de Onetti - el registro queda acusado en las cartas de 1937-del concepto de realismo mágico según el análisis pictórico de Franz Roh, historiador alemán de arte europeo. Asimismo, este trabajo enmarcará el desarrollo de la categoría realismo mágico en la Literatura Latinoamericana en tanto resolución diferenciada a los problemas del realismo tradicional y en cuanto diferenciación resolutiva por parte de Onetti y su realismo solipsista.

PALABRAS ClAVE: Juan Carlos Onetti, realismo mágico, Franz Roh, realismo solipsista, literatura latinoamericana, arte y literatura de vanguardias.

\begin{abstract}
In considering the corpus of 37 letters sent by Juan Carlos Onetti to the Argentine critic and art historian Julio E. Payró between 1937 and 1955, I set to analyze a number of topics and questions that become highly relevant for Onetti's poetics. It becomes essential here to consider Onetti's reception of the concept of realismo mágico (magical realism), which is connected-as shown in the 1937' letters-with the analysis performed by the German art historian Franz Roh. This article will take the development of the category of realismo mágico in two ways. First, in placing it within Latin American Literature, as something different from the topics of traditional realism. Second, as constituting a resolutive differentiation that belongs to Onetti's solipsistic Realism.
\end{abstract}

KEYWORDS: Juan Carlos Onetti, magical realism, Franz Roh, solipsistic Realism, Latin American Literature, avant-garde literature and art. 
A partir de la publicación en 2009 de las cartas ${ }^{1}$ que el escritor uruguayo Juan Carlos Onetti mantuvo con Julio E. Payró -prestigioso crítico e historiador del arte de intensa actividad y reconocimiento tanto en el ámbito porteño como en el montevideano- desde el año 1937 hasta mediados de la década del 50 (una temporalidad histórica que no deja de tener su relevancia tal como expondremos en su momento, ya que se trata del período inmediato a las vanguardias históricas enlazona del Río delaPlata, en el cual la estética queprevalecía en la narrativa era la de lo Fantástico), conocemos desde otro punto de vista el período de formación como escritor del autor de La vida breve (1950), entre otras destacadas obras de la literatura hispanoamericana. Desde la primera misiva, fechada en 1937, Onetti -a los 28 años de edad- hace gala tanto de su nutrida competencia cultural en el campo artístico contemporáneo como de su dilatado conocimiento sobre lo clásico. Pululan menciones a dramaturgos y piezas de teatro franceses de la década del 20 y del 30, mezcladas con alusiones a la mitología griega o la tradición europea. Sin embargo, el tono es afable y relajado como quien conversa en un café con un interlocutor muy preparado -Payró ya es, como mencionamos antes, un reconocido crítico e historiador del arte en el ámbito del Río de la Plata-pero no siente en absoluto la obligación de rendir un examen. Entre las múltiples referencias a la alta cultura se filtran fragmentos de letras de tangos y giros coloquiales que transmiten de lleno el acento cómplice y afectuoso de los corresponsales. En esta misma primera carta relevamos la liminar mención del realismo mágico en lo que respecta aHispanoamérica. Onetti comentay deja asentado su conocimiento del libro del especialista alemán en arte Franz Roh, de 1925, sobre la pintura europea post-expresionista realismo mágico. Post expresionismo. Problemas de la pintura europea más reciente. Este último título corresponde a la versión española de 1927 traducida por Fernando Vela y editada en Madrid por la Revista de Occidente.Onetti fecha en esta epístola de 1937 su pionera recepción de los escritos del historiador del arte alemán. Verani lo certifica:

\footnotetext{
En la primera carta conservada, Onetti menciona El realismo mágico de Franz Roh, dedicado a la pintura europea post-expresionista de la década de los veinte, pero su interés es muy diferente y, mucho más preciso, de la lectura que harán una década después Alejo Carpentier, Arturo Uslar Pietri, Miguel Ángel Asturias y otros. Carpentier construye su poética en términos del contexto, de un referente extraliterario, asociado a la naturaleza inverosímil que pinta Henri "El aduanero" Rousseau, junglas tropicales supuestamente veracruzanas; plantea una imagen del mundo que presupone una fe en las fuerzas primitivas, indígenas o afro americanas, y en leyendas populares, introduciendo, al mismo tiempo, una categoría estética muy difundida entre los latinoamericanistas. Onetti, en cambio, comenta el realismo mágico en su acepción delimitada, sin distorsionar el sentido propuesto por Roh. (Verani, 2009a, p. 11)
}

1 Onetti, Juan Carlos. (2009) Cartas de un joven escritor. Correspondencia con Julio E. Payró editado, anotado e introducido por Hugo J. Verani. Montevideo: Trilce. Contiene 67 cartas de Onetti a Payró. En adelante se mencionará como Epistolario y nos referiremos a las epístolas remarcando su numeración entre []. 
A partir de la liminar mención de la lectura del libro de Roh consideramos imprescindible abordar el análisis del entramado de relaciones que se suscita entre los preceptos fundamentales que releva el volumen crítico del historiador del arte, los datos apuntados en la correspondencia de Onetti y las innovaciones técnicas que realiza este último en su escritura alrededor de esos años. La pintura post-impresionista europea se erige como uno de los puntos de contacto, que decanta de la insistente mención en el Epistolario por parte de Onetti, entre la estética del narrador uruguayo y la teorización del especialista alemán. Paul Cézanne, Paul Gauguin o "el Aduanero" Rousseau son nombres que abundan en las misivas a Payró y, asimismo, son representantes primarios de la corriente o período post-impresionista (1886-1906); esta matriz pictórica está en la base del período post-expresionista (1920-1925) de la pintura europea, ciclo examinado por Roh².

En su advertencia preliminar, Roh fundamenta su decisión de nominar realismo mágico a su investigación a los fines de investir de sentido el descriptor "post-expresionismo". Su objetivo es condensar bajo esta cláusula las figuraciones artísticas de la pintura europea de los últimos cinco años (1920-1925):

No doy valor especial al título de realismo mágico. Como la obra tenía que llevar un nombre significativo, y la palabra "post-expresionismo" solo dice abolengo y relación cronológica, he añadido el primer título bastante después de haber escrito la obra. Me parece, al menos, más acertado que "realismo ideal" o "verismo" o "neoclasicismo" que solo designan un aspecto del movimiento. "Suprarrealismo" significa, por ahora, otra cosa. Con la palabra "mágico" en oposición a "místico", quiero indicar que el misterio no desciende al mundo representado, sino que se esconde y palpita tras él [...]. (Roh, 1927, "Advertencia preliminar" a realismo mágico...., s/p.).

El historiador y crítico de arte identifica y reúne variaciones respecto del bloque del expresionismo, estética prevaleciente hasta 1920, en un exhaustivo trabajo comparativo de las formas, líneas, texturas y colores. Postula como factor en común del impresionismo, el expresionismo y el post-expresionismo su capacidad "contra la reproducción extrínseca del mundo", y cataloga los procedimientos que encara cada una de estas tendencias para lograrlo: "la primera, por la perespiritualización de la luz y el aire; la segunda, merced a la esquematización cubista de toda intuición; y la tercera, mediante la rigorosa separación y solidificación de lo que llamamos objetos" (Roh 1927, p. 25). En conjunto, podemos remitir estas modulaciones "contra la reproducción extrínseca del mundo" -o modo realista clásico de representación, en términos literarios- a diversas estrategias que Onetti incorpora en sus narraciones desde los comienzos de su escritura. En 1981, con la publicación de Onetti:

2 Roh propone y sostiene estas periodizaciones exactas, pero deja en claro que la intención es de índole didáctica, ya que los estilos pictóricos se fusionan y entremezclan, como es lógico, más allá de la datación estricta. El ciclo intermedio que corresponde al segmento entre las fechas descriptas es, por supuesto, el expresionismo. 
el ritual de la impostura Verani se encolumna entre los pioneros críticos que rastrean e identifican los mecanismos de creación literaria del narrador uruguayo. El crítico uruguayo sostiene que Onetti, aun antes de la aparición de $L a$ vida breve, desde sus primeras novelas -Elpozo (1939), Tierra de nadie (1941), Para esta noche (1943) - provoca un proceso de "desrealización" apuntalado por la configuración fragmentaria y un estilo "alusivo-elusivo" que sugiere sin definir dando por resultado "la imagen de un mundo cotidiano, pero es un mundo mítico (íntimamente ligado a la realidad, sin duda, aunque nunca supeditado a ella), en el cual el acto creador predomina sobre la reproduccción pasiva de comportamientos y situaciones observadas en la vida misma” (Verani, 1981, p. 25).

\section{EL MÉTODO COMPARATIVO}

Franz Roh basa en el método comparativo su búsqueda de diferencias entre el período expresionista y el post-expresionista, cuatro son las etapas que identifica en lo que denomina sistema expresionista:

1- El momento inicial, para Roh, tiene lugar en 1890 con la publicación del "manifiesto de Van Gogh, Gauguin y sus amigos", luego en 1902 se fundará en Alemania el movimiento "die Brücke" (El puente), compuesto por la vanguardia de pintores noralemanes. La simplificación plástica ylineal dominante tiene por objeto transfigurar la naturaleza real de lo representado, aun cuando en esta primera instancia el mundo de los objetos permanece intacto: "la realidad espacial de un paisaje, por ejemplo, subsiste, aunque, resueltamente deformada en pro de un nuevo orden sistemático" (Roh, 1927, p. 26, destacado nuestro). En la carta [3] del epistolario Onetti reúne los nombres de Van Gogh y Gauguin para contrastarlos con el de Cézanne. Relata cómo ha pasado muchas horas observando "la Mujer con fruto" de Gauguin y concluye que ese cuadro es "matemáticamente perfecto" y que se destaca por sobre la obra de Cézanne porque "dentro de un orden severo, hay allí toda la poesía que hasta la fecha es posible poner en un cuadro" (Onetti, [3], p. 42, destacado nuestro). Onetti elogiará la obra de Cézanne en reiteradas ocasiones en el resto de su epistolario, perolo que nos interesa observar en este punto es el hecho de apreciar, por parte del escritor uruguayo, en el cuadro de Gauguin, una de las principales características que registra Roh en la primera etapa expresionista, el "orden sistemático o severo".

2- Aparición del cubismo y la "pintura absoluta" a partir de la primacía del color sobre la forma. Este desplazamiento redunda en la volatilización de los objetos, la difuminación progresiva de sus contornos reconocibles. Los resultados arrojan la combinación de los valores del espacio mediante una proporcionalidad arquitectónica de bloques, como el cubismo, o la plasmación de formas en apariencia improvisadas, como en Kandinsky. Onetti adopta en sus descripciones varios de estos preceptos, la estrategia de la "deformación” le 
garantiza una resolución original para la transmisión del punto de vista de sus personajes. En la novela corta Los adioses (1954) encontramos un claro ejemplo de esta estrategia descriptiva, así lo entiende José Pedro Díaz (1987) cuando analiza el principio del relato, específicamente su segundo párrafo:

\begin{abstract}
Quisiera no haberle [al hombre] visto más que las manos, me hubiera bastado verlas cuando le di el cambio de los cien pesos y los dedos apretaron los billetes, trataron de acomodarlos y, en seguida, resolviéndose, hicieron una pelota achatada y la escondieron con pudor en un bolsillo del saco; me hubieran bastado aquellos movimientos sobre la madera llena de tajos rellenados con grasa y mugre para saber que no iba a curarse, que no conocía nada de donde sacar voluntad para curarse (Onetti, 2009, Novelas cortas, p. 35).
\end{abstract}

José Pedro Díaz observa cómo a través de la descripción de las manos del recién llegado al almacén, el almacenero - personaje narrador del relato-transmite los estados de ánimo del visitante y las consecuencias de esto sobre el desenlace de la historia en apenas unas líneas: "Además, estas mismas frases participan también de una fuerte ambigüedad, porque aluden a lo que el personaje -"el hombre"- siente, según imagina -¿por qué?- el narrador. Quien narra no es la tercera persona omnisciente, sino concretamente el dueño del comercio donde "el hombre" toma una cerveza. La utilización de la técnica del punto de vista nos hace participar de un pensamiento del protagonista que proviene de otro personaje, quien, sobre lo que ve, imagina" (Díaz, 1987, p. 97, destacados nuestros). Estos inhabituales puntos de vista a los que antes aludimos, encuentran en Onetti siempre un asidero en sus constructos descriptivos. Por lo general, uno de sus narradores califica de un modo particular lo que observa para transmitirlo a otro personaje o directamente al lector. Es el caso de otro de los fragmentos de esta misma nouvelle:

\footnotetext{
El hombre entró con una valija y un impermeable; alto, los hombros anchos y encogidos, saludando sin sonreír porque su sonrisa no iba a ser creída y se había hecho inútil y contraproducente desde mucho tiempo atrás, desde años antes de estar enfermo. Lo volví a mirar mientras tomaba la cerveza, vuelto hacia el camino y la sierra; y observé sus manos cuando manejó los billetes en el mostrador, debajo de mi cara. Pero no pagó al irse, sino que se interrumpió y vino desde el rincón, lento, enemigo sin orgullo de la piedad, incrédulo, para pagarme y guardar sus billetes con aquellos dedos jóvenes envarados por la imposibilidad de sujetar las cosas (Onetti, 2009, Novelas cortas, p. 36, destacados nuestros).
}

Dijimos antes "constructo descriptivo"; nótese en ambos destacados de la cita la armazón de tres elementos concatenados para calificar al personaje: ya sea con una triple adjetivación, "triadjetivación", como en el segundo caso; o ya sea con una combinación de dos atributos y un gerundio, "trinomio", como en el primero. Como en estos dos ejemplos, la composición descriptiva en Onetti muchas veces encabalga en sus oraciones dos términos pertenecientes 
o relativos a un único campo semántico con un tercero totalmente ajeno al mismo. La lentitud no está relacionada directamente con lo impío o lo incrédulo, dos atributos que pertenecen efectivamente al mismo universo de sentido; asimismo, la caracterización de la complexión física del visitante relaciona la altura con el formato de la espalda, pero deja afuera por completo el modo de sonreír del sujeto. Esta logradísima y repetida operatoria descriptiva por parte de Onetti proporciona al lector la información "deformada" de un modo muy particular, o sea, desde el ángulo o punto de vista que sus personajes narradores decidan abordar.

3- Surge el "constructivismo" como superación de un arte en particular a través de la fusión de la pintura, la escultura y la arquitectura. Nuevos efectos de líneas, de superficies, de cuerpos y renovados materiales aportan su innovación técnica, "la máquina, con su poderosa mecánica, se convierte en símbolo y modelo" (Roh, 1927, p. 27). Se plantea un nuevo racionalismo contra la "desidiosa" tendencia a lo natural, a la "evolución orgánica", asistimos al reposicionamiento de la inteligencia frente a lo instintivo, de la máquina ante lo animal. Joaquín Torres García, el más reconocido y emblemático pintor uruguayo, definió su estética como "constructivismo" y poco después le aplicó la denominación de "universalismo constructivo". Se trata de un arte de gran contenido ideológico, ya que aspiraba a dar una visión unitaria del Mundo por medio de una rígida estructura y de un esquematismo formal y colorístico, sin llegar a la abstracción total. Por esolas obras del pintor están llenas de alusiones a la realidad, como propone Jardí: "Torres García incluye en los recuadros de sus composiciones, representaciones de objetos usuales: un reloj, un martillo, un áncora, o bien figuraciones de seres vivientes: un pez, un hombre. Así el contemplador de esta especie de jeroglífico nunca llega a tener la impresión de estar desligado de la realidad perceptible”. (Jardí 1987, p. 98, destacado nuestro). En consonancia con las resoluciones formales que proponemos en la obra de Onetti, el componente constructivista resulta evidente en tanto la operación de montaje y desmontaje del realismo conserva la remitencia al referente, no se desliga totalmente de esa realidad perceptible.

4- Como estadio ulterior del expresionismo Roh propone el subgrupo del "futurismo", entendido este como el mecanismo capaz de captar y transmitir "de un modo singular la emoción de simultaneidad". En la tela se pinta yuxtapuesto lo que en el tiempo está separado; ahora las fases sucesivas se representan simultáneas, formando una única acción. El ensamble de estas escenas temporoespaciales amalgamó "los fragmentos de la realidad más palpable con las curvas más abstractas, de modo que estas ensambladuras y perforaciones producían el efecto de fuerzas enigmáticas palpitando tras las cosas" (Roh 1927, p. 30). Aquí, en este particular efecto reside el "realismo mágico de Franz Roh, quien advertía al lector al comenzar su libro: “[...] con la palabra 'mágico' en oposición a 'místico', quiero indicar que el misterio no desciende al mundo 
representado, sino que se esconde y palpita tras él..." (Roh, 1927, Advertencia preliminar, s/p).

La relevancia de este último fragmento se potencia si tomamos en cuenta lo que define por negatividad, es decir, cuando Roh refiere que el "misterio no desciende al mundo representado" descarta uno de los postulados básicos del tópico fantástico. En el prólogo a la Antología de la literatura fantástica (1940), de J. L. Borges, Silvina Ocampo y A. Bioy Casares, firmado por éste último, se afirma que una de las leyes básicas para identificar un texto con el género antologizado es "que en un mundo plenamente creíble sucediera un solo hecho increíble; que en vidas consuetudinarias y domésticas, como las del lector, sucediera el fantasma" (Bioy Casares, 1940, p. 6-7, destacado nuestro). Por fantasma, en este prólogo, Bioy entiende sucesos sobrenaturales (aparición de espectros o ánimas) o metafísicos (más allá de las leyes de la física, como viajes en el tiempo, por ejemplo). Entonces, al descartar el "descenso" o aparición ex nihilo del fantasma, Roh invalida entre los rasgos de la pintura analizada el componente fantástico, deslinda la intromisión milagrosa o paranormal. Del mismo modo opera Onetti en la elección de una estética que descarta de plano el acontecer de hechos sobrenaturales, pues en su narrativa siempre se conserva el dispositivo perceptual afincado en los cánones realistas. En esta instancia Roh considera "el sueño" como posible fundamento exterior de estas unidades pictóricas que consiguen el deseado efecto dinámico de simultaneidad y, a la vez, poseen el enigmático efecto palpitante: durante el "sueñolas vivencias parciales se empujan y comprimen unas a otras, en misterioso combate y penetración" $(1927$, p. 31). Ya no en el terreno onírico sino en el de la ensoñación de la vigilia o el - 'soñar despierto' -, los personajes de Onetti agolpan deseos, vivencias y situaciones en un fluir desbocado de la conciencia, no de la inconsciencia. La organización de tales elementos en el relato se cumplimenta a través de las operaciones vanguardistas de incrustación, montaje y salto de planos, monólogos interiores, entre otras.

\section{LOS NUEVOS OBJETOS Y LA VUELTA A LA OBJETIVIDAD}

La corriente expresionista determina como plausible de reproducción, en flagrante reacción contra el impresionismo, el conjunto de objetos fantásticos, supraterrenales y remotos. Cuando refiere a lo cotidiano y corriente, lo representa distante o transfigurado en un "exotismo chocante". Estos son los tópicos principales que serán desplazados por los nuevos del post-expresionismo para Roh. El especialista alemán presta mucha atención al hecho de que este último movimiento pareciera disipar por completo "el ensueño fantástico y cómo "nuestro verdadero mundo resurge ante nuestros ojos" (Roh, 1927, p. 36, destacados nuestros). En la tematización de la pintura post-expresionista verificamos un retorno a lo terrenal, temas trascendentales y religiosos desa- 
parecen casi por completo en la selección de autores de Roh-Carrá, Chirico, Citroën, Schrimpf, Mense, Spies, Severini, entre otros. Como apuntábamos arriba, el misterio no desciende, palpita detrás de estos objetos ordinarios que se invisten de "una significación más honda y rozan misterios que están amenazando siempre la tranquila seguridad de los simples e ingenuos" y continúan "siendo ajenos al concepto corriente del realismo" (p. 37). Esta última aseveración posiciona al post-expresionismo en el vaivén al que -en palabras de Roh-el arte siempre se siente compelido, esto es, el devenir entre la devoción al mundo del ensueño y la adhesión al mundo de la realidad. El movimiento, finalmente, inclina la balanza hacia el restablecimiento de la objetividad $^{3}$ y se expresa en la antedicha elección de un universo más mesurado de temas.

Para el impresionismo la existencia de los objetos va de suyo, pues este movimiento considera evidente la presencia en la pintura de los elementos que conforman un mundo. Para el expresionismo también existían estos objetos, pero esterevalidó su sentido en los niveles y ritmos de la forma al punto de desintegrar sus contornos; la composición, la disposición y entramado de líneas y colores supeditan a la mínima trascendencia la captación del objeto. Desde el post-expresionismo se pretenderá "reintegrar la realidad en el nexo de la visibilidad", la pintura como espejo de la exterioridad palpable, pero -aclara Roh- "sin aludir para nada a esa actitud instintiva que estuvo vinculada a los últimos realismos del arte europeo" (1927,p. 39). Cuando el expresionismo ha arribado ya a su cuarta estancia, es decir, al "futurismo"-siempre en términos de Roh- la necesidad de reproducción de lo simultáneo arriba a su apoteosis y el post-expresionismo se hace cargo captando "en medio de un tumulto uniforme de trazos de pura composición [...] este enigma de toda quietud en medio del general devenir, de la universal disolución" (p. 45). Centrando sus procedimientos en torno al objeto referencial -traspasando la superficie lineal- los artistas post-expresionistas coagulan un estilo que se sitúa entre los extremos del sensualismo informe (expresionismo) y el esquematismo superestructurado (mimesis duplicadora): "La pintura siente ahora la realidad del objeto y del espacio, no como una copia de la naturaleza, sino como una segunda creación" (p.48). A partir de esta definición de Roh, se puede deducir que la postura post-expresionista practica un rechazo a la mimesis fidedigna y transcriptora del mundo de lo real y se acerca a la noción de creacionismo de las vanguardias históricas (Vicente Huidobro y Pierre Reverdy, vertiente que dicho sea de paso Onetti rescata y textualiza en sus ficciones ${ }^{4}$ ) y que, como

3 Al finalizar el libro, Roh brinda una lista de más de cincuenta pintores que trabajan en la dirección post-expresionista. La mayoría de ellos integrarán una gran exposición organizada en el Palacio de Arte de Manheim, en 1925, por Gustav Hartlaub bajo el título Die Neue Sachlichkeit (La nueva objetividad), término que desplazará, en el ámbito de la pintura, por mucho tiempo, al concepto de realismo mágico.

4 Por supuesto nos referimos a la creación de Santa María por parte de Juan María Brausen y a otras invenciones incorporadas por sus personajes narradores, como el caso de la "idea-chivo" signada por Ambrosio, el proxeneta perfeccionador de la historia de Rita y el chivo en Para una tumba sin nombre (1959). 
sabemos, tendrá en el invencionismo de las vanguardias de los 50 y 60 una continuidad natural.

Por el registro de las cartas dirigidas a Payró, ya hemos analizado el profundo interés estético que Onetti tenía por la tríada de pintores post-impresionistas europeos-Cézanne, Gauguin, "el Aduanero" Rousseau-de fines del siglo xix y principios del xx. Coincidentemente, estos artistas encarnan las principales influencias de los post-expresionistas propuestos por Roh como los renovadores de la pintura en la segunda década del siglo xx. El resultado, o uno de ellos al menos, de la lección artística que Onetti aprehende de la pintura post-impresionista se verá reflejado, para Verani, en la destreza técnica que incorpora en su escritura. Procedimientos tales como la mezcla de planos, yuxtaposiciones y simultaneidades espaciales y temporales, descripciones, manejo de la luminosidad de las escenas, entre otros, remiten directamente-aunque no de modo exclusivo- a la tenaz observación por parte del narrador uruguayo de la obra de los pintores de la corriente mencionada.

\footnotetext{
El cambio esencial en la pintura post-impresionista -la que apasiona a Onetti y que resurge en el arte de los veinte y los treinta, estudiado por Roh, consiste en una vuelta a lo real, a una nueva objetividad, $y$, ante todo, a una estética que no quiere ser imitativa, descriptiva o anecdótica, ni es un reflejo de la naturaleza, sino una creación que reconstruye el mundo de lo visible, poniendo de manifiesto la convivencia de lo objetivo y lo subjetivo, lo irracional y lo racional. Lo que importa es la composición, el poder de la ensoñación para dictar escenas, conservándose el dominio de lo reconocible, el flujo de la vida real proyectada a un plano interior (Verani, 2009b, p. 11, destacado nuestro).
}

De la convivencia entre lo objetivo y lo subjetivo, entre lo irracional y lo racional surge el matiz misterioso que tiñe los textos de Onetti, acaso el misterio de lo mágicorrealista -en ningún caso místico o sobrenatural, retomando a Roh-sin desasir el "dominio de lo reconocible", a la manera de los postexpresionistas, poseedores de una conciencia plena de los contornos realistas de la figura y de las posibilidades de su distorsión ${ }^{6}$. En el accionar narrativo de Onetti, como venimos sosteniendo, esta operación de armado y desarmado de los cánones del realismo - de postulación de narradores omniscientes que resultan reconfigurados en múltiples personas gramaticales y puntos de vista, de desdoblamientos, de intersticios temporales que modifican y desactivan la linealidad cronológica de la saga sanmariana, entre otros procedimientos- se nutre durante toda su "etapa de formación como escritor" de las lecciones estéticas no solo de la literatura sino de manera sustancial de la pintura contemporánea.

5 Por "dominio de lo reconocible" consideramos, con Roh, la diferencia sustancial entre el post-expresionismo respecto del expresionismo, es decir, el retorno a la delimitación de la figura, la restitución del contorno, que había sido abandonada por los procedimientos "deformantes" del arte expresionista.

6 Procedimiento ya extremado por sus inmediatos antecesores, los expresionistas. 


\section{APROPIACIÓN DEL TÉRMINO REALISMO MÁGICO}

El título original del libro en alemán del crítico e historiador del arte Franz Roh es Nach- Expressionismus, magischer Realismus. Probleme der neuesten europaischen Malerei, de $1925^{7}$. Cuando sea traducido dos años más tarde, 1927, por Fernando Vela, a instancias de José Ortega y Gasset y en edición de su Revista de Occidente el título se convertirá en realismo mágico. Postexpresionismo. Problemas de la pintura europea más reciente ${ }^{8}$. Es notorio el hecho de la inversión de la cláusula principal del título de la versión alemana a la edición española, por lo cual el sintagma "realismo mágico" supedita directamente al de "Post-expresionismo" y aún más: al de Problemas de la pintura europea más reciente -en la edición española la tipografía de mayor tamaño y destaque del primer sintagma diferencia y somete claramente a los otros dos. Además, llama la atención que en la portada misma el nombre de Franz Roh se reproduce, dominante sobre el resto del texto, con una tipografía de tipo cubista en colores rojo y negro en composición cuasi quiasmática y con el detalle de la reproducción de un pequeño objeto - al parecer un florero perteneciente a una/s de las tantas "naturalezas muertas" analizadas por Rohcompuesto por una mitad que obedece a la línea expresionista y la otra mitad de clara línea post-expresionista, objeto inexistente en la versión original alemana?.

De esta manera se destaca, en la edición española, una elección de realce del nombre del autor y de la categoría "realismo mágico" sobre la de "post-expresionismo". Jerarquización que contrasta no solo con la cubierta del libro original en alemán, sino con la primera parte de la advertencia preliminar donde Roh deja bien en claro que "no doy valor especial al título de 'realismo mágico'. Como la obra tenía que llevar un nombre significativo y la palabra 'post-expresionismo' solo dice abolengo y relación cronológica, he añadido el primer título bastante después de haber escrito la obra." (Roh, 1927, Advertencia preliminar a realismo mágico ..., s/p). Se inaugura así, con este efecto de desplazamiento, la apropiación en lengua española de una categoría, el realismo mágico, que desarrollará en Latinoamérica un rico y controvertido periplo ${ }^{10}$.

7 Nach-Expressionismus, magischer Realismus. Probleme der neuesten europaischen Malerei. Leipzig Klinkhardt y Biermann, 1925

8 Realismo mágico. Post-expresionismo. Problemas de la pintura europea más reciente. Traducción de Fernando Vela. Madrid Revista de Occidente, 1927.

9 La elección y colocación de este objeto en la portada del libro, en la edición de Revista de Occidente, impreso en colores rojoy negro en asimétricas mitades se particulariza aún más con el dato de quelas 88 láminas delas pinturas que Roh seleccionó para su volumen alemán se reproducen, en la versión española, en blanco y negro.

10 Unas páginas más adelante retomaremos este tópico y desarrollaremos el devenir de este concepto. 


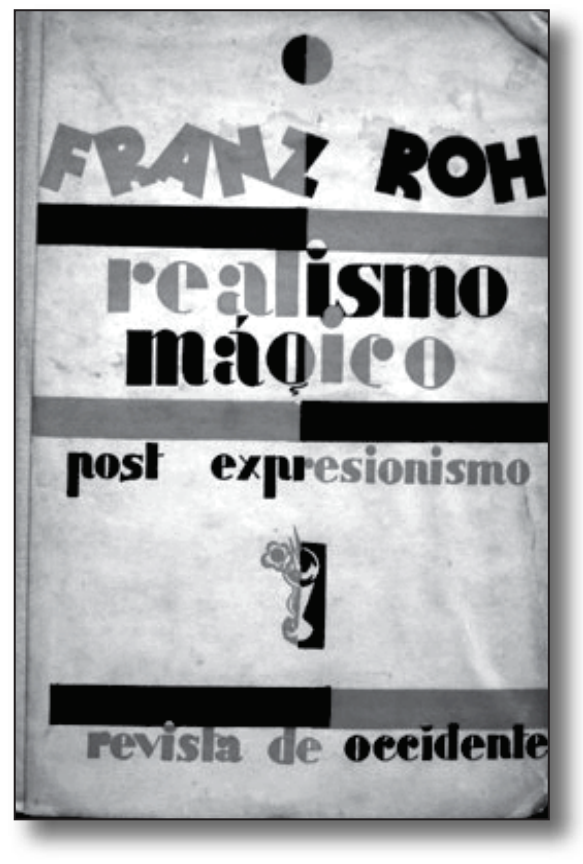

Reproducción portada realismo mágico. Post expresionismo. Problemas de la pintura europea más reciente. Madrid, Revista de 0ccidente, 1927.

Reproducción portada original Nach-Expressionismus, magischer Realismus. Probleme der neuesten europaischen Malerei. Leipzig Klinkhardt y Biermann, 1925.

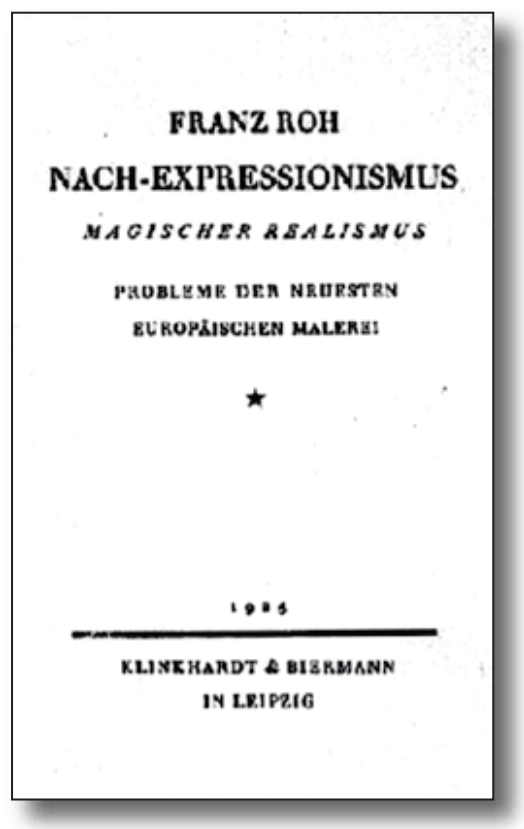

Esta selección tipográfica de contraste de colores y, particularmente, del único objeto reproducido en la portada de la edición de Revista de Occidente asevera y confirma el método comparativo propuesto por Roh para intentar determinar los elementos principales de las estéticas que pretende relacionar en su tesis, o sea, la expresionista y la post-expresionista. Siguiendo el método que su profesor, Heinrich Wöllflin, aplicó unos años antes para comparar el arte renacentista y el arte barroco, Roh puntualiza veintidós características para tomar en cuenta en la diferenciación: 


\section{EXPRESIONISMO - POST-EXPRESIONISMO}

\begin{tabular}{l|l}
\hline $\begin{array}{l}\text { 1. Objetos extáticos } \\
\text { Ekstatische Gegenstände }\end{array}$ & $\begin{array}{l}\text { 1. Objetos planos } \\
\text { Nüchterne Gegenstände }\end{array}$ \\
\hline $\begin{array}{l}\text { 2. Abundante temática religiosa } \\
\text { Viel religiöse Vorwürfe }\end{array}$ & $\begin{array}{l}\text { 2. Escasa temática religiosa } \\
\text { Sehr wenig religiöse Vorwürfe }\end{array}$ \\
\hline $\begin{array}{l}\text { 3. Objetos contenidos, suprimidos } \\
\text { Objekt unterdrückend }\end{array}$ & $\begin{array}{l}\text { 3. Objetos explicitados con una mayor } \\
\text { clarificación } \\
\text { Objekt verdeutlichend }\end{array}$ \\
\hline $\begin{array}{l}\text { 4. Rítmico } \\
\text { Rhythmisierend }\end{array}$ & $\begin{array}{l}\text { 4. Representativo } \\
\text { Darstellend }\end{array}$ \\
\hline $\begin{array}{l}\text { 5. Emocionante, excitante, } \\
\text { suscitador } \\
\text { Erregend }\end{array}$ & $\begin{array}{l}\text { 5. Profundo } \\
\text { Vertiefend }\end{array}$ \\
\hline $\begin{array}{l}\text { 6. Excesivo, desmesurado } \\
\text { Ausschweifend }\end{array}$ & $\begin{array}{l}\text { 6. Bastante estricto, purista } \\
\text { Eher streng, puristisch }\end{array}$ \\
\hline $\begin{array}{l}\text { 7. Dinámico } \\
\text { Dynamisch }\end{array}$ & $\begin{array}{l}\text { 7. Estático } \\
\text { Statisch }\end{array}$ \\
\hline
\end{tabular}

8. Fuerte, enérgico

Laut

9. Sumario, resumido,
concentrado
Summarisch

10. Imagen cercana, evidente, patente Vordergründig (Nahbild)

11. Hacia adelante Nach vorn treibend
8. Tranquilo, calmo Still

9. Sostenido, continuo Durchführend

10. Imagen próxima y lejana, latente, atrás de Vorder-und hintergründig (Nahbild + Fernbild)

11. Hacia atrás, en retroceso Auch zurückfliehend 


\begin{tabular}{|c|c|}
\hline $\begin{array}{l}\text { 12. Gran tamaño } \\
\text { Großformig }\end{array}$ & $\begin{array}{l}\text { 12. Gran tamaño y múltiples } \\
\text { columnas } \\
\text { Großformig + vielspältig }\end{array}$ \\
\hline $\begin{array}{l}\text { 13. Monumental } \\
\text { Monumental }\end{array}$ & $\begin{array}{l}\text { 13. Miniatura } \\
\text { Miniaturartig }\end{array}$ \\
\hline $\begin{array}{l}\text { 14. Caliente } \\
\text { Warm }\end{array}$ & $\begin{array}{l}\text { 14. Fresco, frío } \\
\text { Kühl, bis kalt }\end{array}$ \\
\hline $\begin{array}{l}\text { 15. Coloración gruesa, espesa, } \\
\text { densa } \\
\text { Dicke Farbsubstanz }\end{array}$ & $\begin{array}{l}\text { 15. Coloración fina, delgada capa de } \\
\text { pintura } \\
\text { Dünne Farbschicht }\end{array}$ \\
\hline $\begin{array}{l}\text { 16. Rugoso, áspero } \\
\text { Aufrauhend }\end{array}$ & $\begin{array}{l}\text { 16. Liso, suave, removido } \\
\text { Glättend, vertrieben }\end{array}$ \\
\hline $\begin{array}{l}\text { 17. Como roca desnuda, en bruto } \\
\text { Wie unbehauenes Gestein }\end{array}$ & $\begin{array}{l}\text { 17. Como de metal pulido, bruñido } \\
\text { Wie blank gemachtes Metall }\end{array}$ \\
\hline $\begin{array}{l}\text { 18. Proceso de trabajo (factura) y } \\
\text { conservación de rastros } \\
\text { Arbeitsprozeß (Faktur) spüren } \\
\text { lassend }\end{array}$ & $\begin{array}{l}\text { 18. Borramiento del proceso de } \\
\text { trabajo (pura objetivación) } \\
\text { Arbeitsprozeß austilgend (reine } \\
\text { Objektivation) }\end{array}$ \\
\hline $\begin{array}{l}\text { 19. Deformación expresionista de } \\
\text { los objetos } \\
\text { Expressive Deformierung der } \\
\text { Objekte }\end{array}$ & $\begin{array}{l}\text { 19. Armónica limpieza de los objetos } \\
\text { Harmonische Reinigung der } \\
\text { Gegenstände }\end{array}$ \\
\hline $\begin{array}{l}\text { 20. Riqueza de diagonales, con } \\
\text { predominancia de ángulos agudos } \\
\text { Diagonalreich (in Schrägen), oft } \\
\text { spitzwinklig }\end{array}$ & $\begin{array}{l}\text { 20. Ángulos rectos, paralelos al marco } \\
\text { Eher rechtwinklig, dem Rahmen } \\
\text { parallel }\end{array}$ \\
\hline $\begin{array}{l}\text { 21. Trabajando contra los bordes } \\
\text { de la imagen } \\
\text { Gegen die Bildränder arbeitend }\end{array}$ & $\begin{array}{l}\text { 21. Afirmados dentro de los bordes de } \\
\text { la imagen } \\
\text { In ihnen festsitzend }\end{array}$ \\
\hline $\begin{array}{l}\text { 22. Primitivo } \\
\text { Urtümlich }\end{array}$ & $\begin{array}{l}\text { 22. Civilizado, cultivado } \\
\text { Kultiviert }\end{array}$ \\
\hline
\end{tabular}


A modo de ejemplificación del pasaje de la pintura expresionista hacia la post-expresionista reproducimos tres series comparativas de láminas del libro de Roh seguidas por las glosas que el mismo autor anotó como epígrafes analíticos de las imágenes.
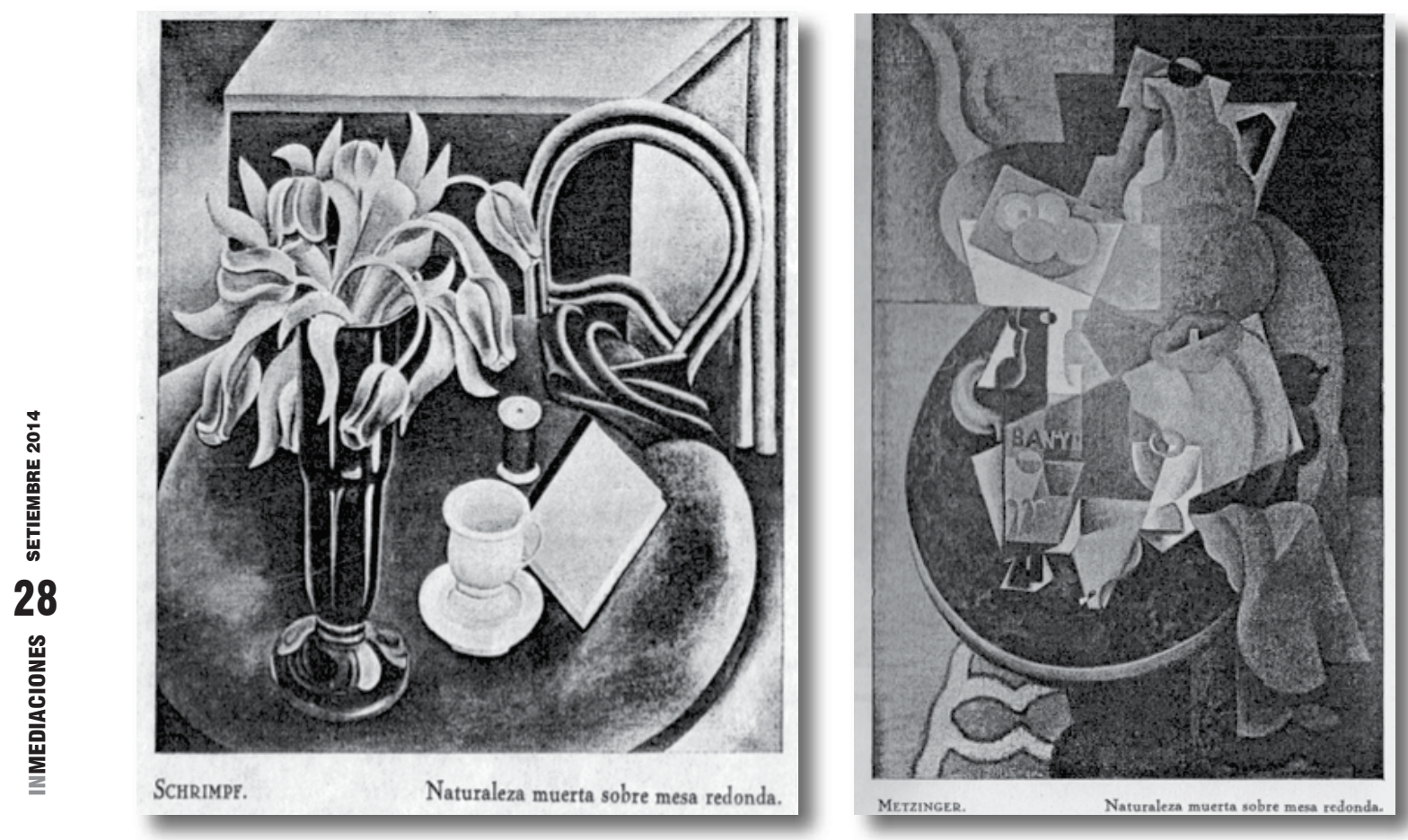

Naturalezas muertas sobre mesa redonda

\begin{abstract}
"En la obra de Schrimpf se observa la nueva solidez en la sustancia de realidad y fuerza espacial con que están extendidos la mesa, las plantas, los utensilios. En Metzinger (que después ha variado), casi los mismos utensilios; pero lo que más se afirma es la redondez de la mesa. Por lo demás, saltos audaces de la perspectiva horizontal a la vertical; atrevidas ensambladuras, despedazamientos y penetraciones de los objetos. En lugar de esos ritmos galopantes y atropellados, hay, en la obra de Schrimpf, la constancia de la melodía." (Roh, 1927, p. 136).
\end{abstract}

El capítulo número 7 de La vida Breve se titula "Naturaleza muerta", en él se describe minuciosamente, desde el punto de vista del narrador Brausen, el interior de un departamento vecino como si se tratara de un escenario pictórico. Sabido es que en una entrevista realizada por Luis Harss (1966) Onetti declara que esa "escenografía inmutable fue "robada" de una naturaleza muerta de [Iván] Albrigth - una acuarela para una edición de lujo de El retrato de Dorian Grey (título sugestivo)- [...]" (Harss, 1981, [1966], p. 
230). La novedad la aporta el agudo ensayo de Laura Pollastri, "La opinión del espejo: ficción e imagen en la escritura de Juan Carlos Onetti” (mimeo), en donde la especialista no solo identifica la pintura de Albrigth señalada por Onetti sino que recaba el modus operandi del escritor y formaliza un significativo agregado al modo de lectura de la representación en la obra del uruguayo. "Wherefore Now Ariseth the Illusion of a Third Dimension" (1931), es el nombre del cuadro -informa Pollastri, y traduce "Por eso ahora surge la ilusión de una tercera dimensión”- de Iván Albright (Estados Unidos, 1897-1983). Albrigth es clasificado, en la historia del arte, como un pintor perteneciente a la corriente mágicorrealista, reconocido por su tratamiento de los temas de la muerte, la vida y el acaecer del tiempo y por la factura de la pintura del Dorian Grey avejentado, encargada para la película hollywoodense El retrato de Dorian Gray (1945), basada en la homónima novela de Oscar Wilde, dirigida por Albert Lewin. Onetti toma en La vida breve la lección Albrigth en la minuciosa descripción de la escena, que reproducimos íntegra para graficar el uso en común entre las estrategias estilísticas del uruguayo y las técnicas mágicorrealistas del pintor estadounidense:

La luz caía verticalmente del techo y luego de tocar los objetos colocados sobre la mesa los iba penetrando sin violencia. El borde de la frutera estaba aplastado en dos sitios y la manija que la atravesaba se torcía sin gracia; tres manzanas, diminutas, visiblemente agrias, se agrupaban contra el borde, y el fondo de la frutera mostraba pequeñas, casi deliberadas abolladuras y viejas manchas que habían sido restregadas sin resultado. Había un pequeño reloj de oro, con solo una aguja, a la izquierda de la base maciza de la frutera que parecía pesar insoportablemente sobre el encaje, de hilo, con algunas vagas e interrumpidas manchas, con algunas roturas que alteraban bruscamente la intención del dibujo. En una esquina de la mesa, siempre en el sector de la izquierda, entre el reloj y el borde, encima de la parte más luminosa, un poco arrugada, de la carpeta de felpa azul, otras dos pequeñas manzanas amenazaban rodar y caer al suelo; una oscura y rojiza, ya podrida; la otra, verde y empezando a pudrirse. Más cerca, sobre la alfombra de trama grosera, exactamente entre mis zapatos y el límite de la sombra de la mesa, estaba caída, arrugada, una pequeña faja de seda rosa, con sostenes de goma, ganchos de metal y goma; deformada y blanda, expresando renuncia y una ociosa protesta. Sin moverme, descubrí debajo de la mesa una pequeña botella tumbada, formas de manzanas que acababan de rodar. En el centro de la mesa, dos limones secos chupaban la luz, arrugados, con manchas blancas y circulares que se iban extendiendo suavemente bajo mis ojos. La botella de Chianti se inclinaba apoyada contra un objeto invisible y en el resto de vino de una copa unas líneas violáceas, aceitosas, se prolongaban en espiral. La otra copa estaba vacía y empañada, reteniendo el aliento de quien había bebido de ella, de quien, de un solo trago, había dejado en el fondo una mancha del tamaño de una moneda. A mi derecha, al pie del marco de plata vacío, con el vidrio atravesado por roturas, vi un billete de un peso y el brillo de monedas doradas y plateadas. Y además de todo lo que me era posible ver y olvidar, además de la decrepitud de la carpeta y su color azul 


\begin{abstract}
contagiado a los vidrios, además de los desgarrones del cubremantel de encaje que registraban antiguos descuidos e impaciencias, estaban junto al borde de la mesa, a la derecha, los paquetes de cigarrillos, llenos e intactos, o abiertos, vacíos, estrujados; estaban además los cigarrillos sueltos, algunos manchados con vino, retorcidos, con el papel desgarrado por la hinchazón del tabaco. Y estaba, finalmente, el par de guantes de mujer forrados de piel, descansando en la carpeta como manos abiertas a medias, como si las manos que habían abrigado se hubieran fundido grado a grado dentro de ellos, abandonando sus formas, una precaria temperatura, el olor a fósforo del sudor que el tiempo gastaría hasta transformarlo en nostalgia. No había nada más, no había tampoco ningún ruido reconocible en la noche ni en el edificio (Onetti, 2005, p. 57-58, destacados nuestros)
\end{abstract}

Varios de los ítems o puntos encuadrados por Roh en la comparación entre el expresionismo y el post-expresionismo pueden deslindarse de la composición de la descripción onettiana, y se revelan solidarios con la pintura de Albright: $\mathrm{n}^{\circ} 3$ objetos explicitados con una mayor clarificación, n 5 profundo, $\mathrm{n}^{\circ} 9$ sostenido/continuo, $\mathrm{n}^{\circ} 14$ fresco/ frío, entre otros. Pollastri apunta la estrategia del escritor: "el autor arma un detallado escenario que parecería convocar la presencia de lo real: los objetos dispuestos, la luz que los ilumina generan una percepción casi táctil de cada uno de los elementos que parecen dispuestos para producir un estado de conciencia: tempus fugit" (destacado nuestro). Como vemos, el paso del tiempo (que el tiempo gastaría hasta transformarlo en nostalgia), la fuga de la juventud (caída, arrugada, una pequeña faja de seda rosa, con sostenes de goma, ganchos de metal y goma; deformada y blanda, expresando renuncia y una ociosa protesta), la pérdida de la frescura de los objetos (dos limones secos chupaban la luz, arrugados), colaboran -como en la pintura del corrompido Dorian Gray hecha por Albright, famoso no solo por sus retratos sino por sus autoretratos llevados a cabo periódicamente hasta el año mismo de su muerte- en la construcción premeditada ("el autor arma un detallado escenario que parecería convocar") del clima enrarecido de una de las tantas vidas breves que Onetti logró, de tan singular manera, hacer deambular por la textura de esta novela.

\footnotetext{
Dos figuras se mueven en la misma dirección por el espacio. Carrá todavía construye por partes estereométricas (fase inicial del post-expresionismo), método que después ha abandonado. Pero en contraposición a Kandinsky, que todavía persevera en la geometría, aun en las obras marcadamente nuevas, Carrá se refiere a un caballo "real" en un espacio "real". Mientras la obra de Kandinsky parece como una aparición de ensueño, en Carrá todo es realidad sólida, la figura es tangible y el espacio invita a entrar en él (Roh, 1927, p. 135).
} 


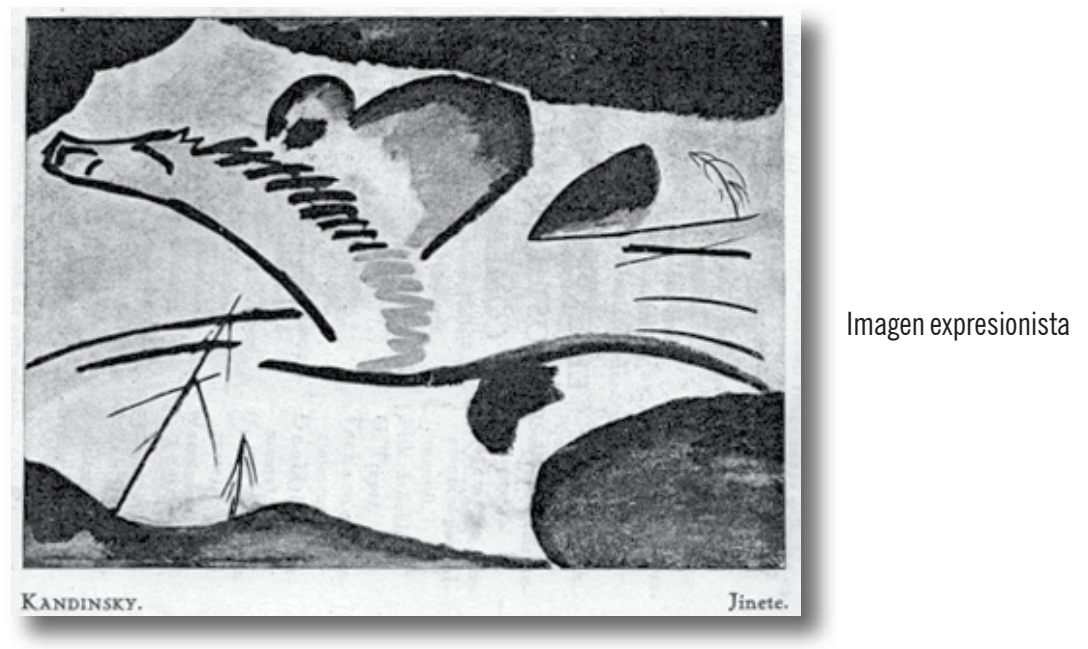

Imagen post-expresionista

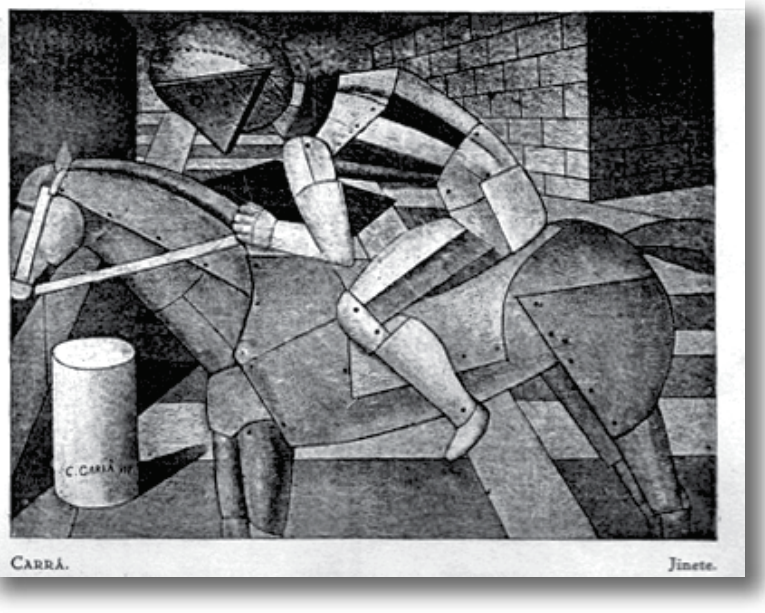

Las cualidades de solidez y tangibilidad del cuadro post-expresionista son logradas por la sumatoria de características que conforman una técnica, por ejemplo observamos cómo son aplicados en la pintura de Carrá los ítems 19 (armónica limpieza de objetos) y 21 (trazos afirmados dentro de los bordes de la imagen) del listado comparativo. Respecto a la "construcción estereométrica"11, que resalta Roh, se torna evidente la preocupación por disponer en la superficie de la tela los elementos de modo estático (ítem 8) y definido o civilizado (ítem 22). Se evita de este modo el efecto de aparición del ensueño en el sentido onírico, presente en el lienzo expresionista de Kandinsky y canalizado en la difuminación de los bordes y trazos cercana a la abstracción (ítems 19, “deformación expresionista de los objetos", y 22, "primitivo"). En la obra de Juan Carlos Onetti, como venimos aseverando, el constructo de ensoñaciones pergeñadas por sus personajes narradores no se corresponde directamente con el ámbito

11 "Estereometría: parte de la geometría que trata de la medida de los sólidos, superficies y volúmenes en el espacio" (diccionario Real Academia Española). El emplazado estereométrico sirve como antecedente al efecto estereoscópico que abordaremos y explicitaremos más adelante. 
onírico, en el sentido de aparición de imágenes inconscientes durante el acto de dormir. En todos los casos, las descripciones que encara la voz narrativa dejan en claro el procedimiento por el cual, durante la vigilia del sujeto, en territorio del "soñar despierto", se procede a elucubrar un guión mental o imaginario. Así se relata desde sus primeros cuentos de la década del 30 ("Avenida de MayoDiagonal- Avenida de Mayo”, 1933, y “El posible Baldi”, 1936) y se reafirma en el método de creación de la ciudad de Santa María.
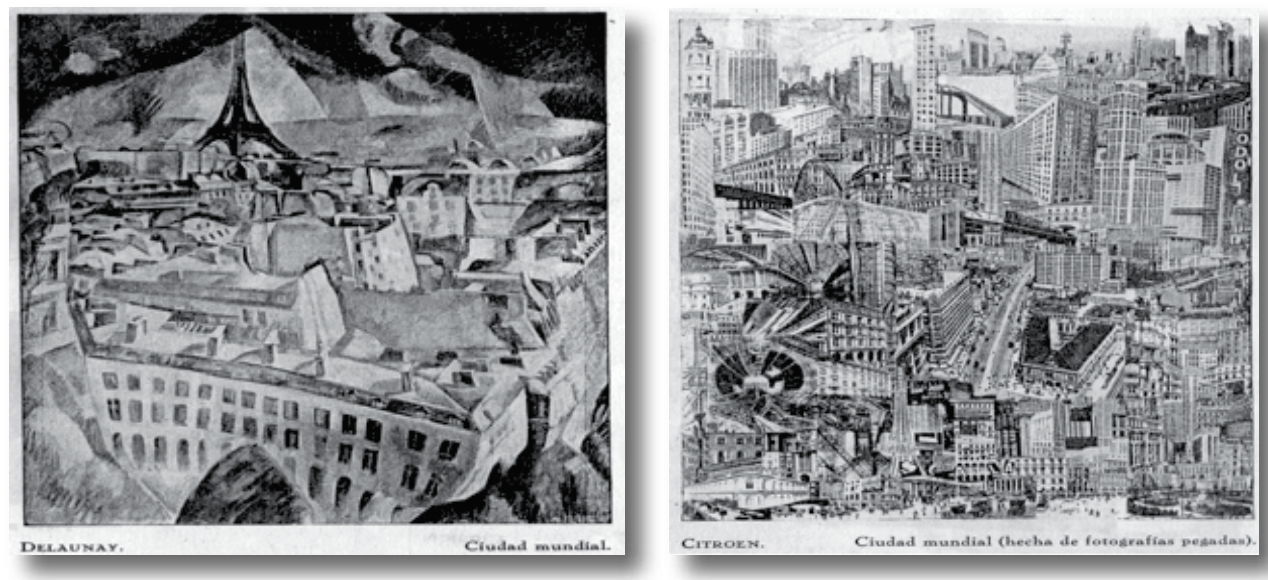

Imagen post-expresionista - Ciudad mundial

\begin{abstract}
Obsérvese en estos dos cuadros, ante todo, la exacerbación de la minuciosidad, que quiere hacer sensible las más pequeñas grietas de los muros, los ínfimos poros de este cuerpo urbano, estrechamente amontonado. Se ve ahora, como por un microscopio, a los hombres pulular en la más honda profundidad de las celdillas de este gigantesco panal. (Minuciosidad en la imagen pegada, pero que no depende de la fotografía, sino al revés: la fotografía se insertó en la pintura, por haberse despertado el goce en la exactitud objetiva). (Roh, 1927, p. 136).
\end{abstract}

El acto de pegar, incrustar fotografías en la tela homologa al procedimiento de incrustación y montaje desarrollado ya en los tempranos relatos de Onetti, como en los cuentos Avenida de Mayo-Diagonal-Avenida de Mayo (1933) o El posible Baldi (1936), o en novelas como Tierra de nadie (1941), por citar solo algunos ejemplos. El dispositivo de descripción de estos contextos urbanos en los relatos mencionados se fundamenta en la permanente espacialización de elementos que irrumpen en el plano de la narración y se posicionan, gráfica y semánticamente, fuera del hilo conductor de la historia. Como en el caso del cuento de 1933, donde el tránsito del personaje de Víctor Suaid es atravesado por los anuncios del visor luminoso instalado en plena vía pública, con la correspondiente interferencia gráfica de destaque del texto publicitario sobre el fluir de la tipografía regular del relato principal. Este es el período onettiano anterior a La vida breve, sindicado por la crítica como realismo urbano. 


\section{AVATARES DE LA NOCIÓN DE "REALISMO MÁGICO” EN LA LITERATURA LATINOAMERICANA}

En 1998 se publica uno de los libros más completos sobre la temática del realismo mágico, nos referimos a Historia verdadera del realismo mágico, de Seymour Menton. El especialista norteamericano -quien estudia esta categoría desdela década del sesenta-se propone, en su completo volumen, demostrar que el realismo mágico es una tendencia artística surgida de la pintura analizada por Roh en la década de 1920 y que en su larga deriva alcanza mayor reconocimiento internacional en la narrativa latinoamericana de los años 60 y 70. En concreto, aboga por una interpretación "internacionalista" dela categoría que no deje afuera los elementos originarios del post-expresionismo alemán y que no pierda de vista la interrelación entre las artes. Ensaya una exhaustiva y muy útil “cronología internacional comentada del término realismo mágico" (Menton, 1998, p. 209) donde recaba las principales recepciones críticas relativas a su objeto de estudio.

Entre las que resultan pertinentes a nuestro enfoque observamos las referencias a una escuela holandesa de pintura que abogó por la preservación del concepto de Roh. En la pintura holandesa, a diferencia de la alemana, el término "realismo mágico" triunfó ante el de "Nueva objetividad", y varios fueron cultores destacados de esta estética. Entre ellos Carol Albert Willink (1900-1983) resultó el más trascendental de su camada para la historia de las artes, sus retratos con un enfoque ultrapreciso abarcan el período desde 1926 hasta los años setenta. Él se autodenominaba, en contraposición al realismo mágico y al surrealismo, cultor de un arte que "es más realismo imaginario" (Menton, 1998, p. 217). Resulta interesante observar que esta denominación de "realismo imaginario" se encuentra relacionada con la concepción que desarrolla respecto de la técnica onettiana el especialista chileno Jaime Concha, quien a su vez resalta la plasticidad visual de las descripciones que evidencia en Onettila posibilidad de "conquista[r] cimas de creación, al dominar una irrealidad que brota, como extraña conciencia, por parte de la realidad, de sus propias y asombrosas posibilidades" (Concha, 2009 [1969], p. 695). Es decir, si estos pintores holandeses, como Willink, utilizaban las técnicas post-expresionistas descriptas por Roh y se autoadscriben a una especie de "realismo imaginario" es plausible afirmar, en la estela interpretativa de Concha, que Onetti sustenta en procedimientos del post-expresionismo o realismo mágico, al menos, algunas de las innovaciones estilísticas de su renovadora escritura.

Menton repasa el reposicionamiento y devenir de la categoría del realismo mágico no solo en la pintura sino también en literatura. Recordemos que para Menton inicialmente, hasta el año 1964, el realismo mágico consiste básicamente en "una precisión exagerada [que] da a la realidad un toque de magia", pero luego muda su postura cuando afirma que "en la literatura, el efecto mágico se logra mediante la yuxtaposición de escenas y detalles de gran realismo con escenas completamente fantásticas"(Menton, 1998, p. 227). 
Interesa la definición completa que brinda en el primer ensayo que compone su libro, El realismo mágico en la pintura y en la literatura internacionales. El gato emblemático:

\begin{abstract}
El realismo mágico es la visión de la realidad diaria de un modo objetivo, estático y ultrapreciso, a veces estereoscópico, con la introducción poco enfática de algún elemento inesperado o improbable que crea un efecto raro o extraño que deja desconcertado, aturdido o asombrado al observador en el museo o al lector en su butaca. (Menton, 1998, p. 20, destacado nuestro).
\end{abstract}

Si dividimos en dos bloques la explícita interpretación de Menton, obtenemos una segunda fraccción-luego de nuestro destacado-que no consideramos atinada porque se contrasta con el ordenamiento básico de complementación de los órdenes natural y sobrenatural sin aparente alteración por parte de las estrategias de narración, y por ende en el efecto de lectura, explicitado por Irlemar Chiampi como característica intrínseca de los textos mágicorrealistas o en su propia terminología "realistas maravillosos"12. En el primer segmento de la definición de Menton, sí destacamos "la visión de la realidad diaria de un modo objetivo, estático y ultrapreciso, a veces estereoscópico". Esta descripción de los modos de observación del artista plástico o autor -el título del capítulo engloba pintura y literatura-conserva las nociones originales de Roh para definir el método post-expresionista o mágicorrealista. El enfoque ultrapreciso es uno de los rasgos más dominantes de la pintura mágicorrealista: si los pintores realistas en general reproducen la mecánica del ojo humano reduciendo la precisión del enfoque para los objetos ubicados en la lejanía (lo que difumina sus contornos y detalles), para muchos post-expresionistas el enfoque ajustado se derrama sobre todos los objetos del cuadro por igual. De tal manera que lo que resulta es un efecto estereoscópico, es decir, que "mirando con ambos ojos, se ven dos imágenes de un objeto que, por estar obtenidas desde puntos diferentes, al fundirse en una, producen una sensación de relieve" (Diccionario de la lengua española 2005. Espasa-Calpe). Procedimientos como el enfoque ultrapreciso o el efecto estereoscópico-y acaso no solo doble sino polivalentemodulan el punto de vista de los narradores en Onetti. Si cuando observamos un objeto, el matiz de otra mirada adiciona referentes y dimensiona lo observado, entonces, la multiplicidad de puntos de vista de un relato otorga volumen a una historia. Cada sesgo manifiesta una perspectiva que engrosa y enriquece la ficción. Dos inferencias al respecto: por un lado, no encontramos personajes ciegos ni tuertos en la ficción onettiana, ningúnpersonaje posee un puntodevis-

12 Llama la atención la no valorización del estudio de Irlemar Chiampi, de 1980, O realismo maravilloso. Forma e ideologia no romance hispanoamericano. Menton incluye el libro en su bibliografía pero no lo considera relevante en la historización de la categoría, nosotros entendemos que Chiampi logra delimitar de manera clara cuáles son los componentes básicos de relación entre términos como fantástico, real maravilloso y realismo mágico. Menton apenas nombra de modo subsidiario, en dos notas al pie, la investigación de Chiampi. Volveremos sobre estos términos en el último apartado de este mismo artículo. 
ta "adelgazado" o falto de relieve, por ende, todo puede ser observado desde un mismo sujeto con diferentes puntos de vista. Por otro lado, las mediatizaciones (vidrios, tabiques, biombos) no ocultan sino que filtran la visión o percepción (escuchas, texturas, olores, sabores) a la manera "estereoscópica".

\section{NI FANTÁSTICOS NI REALISMOS MÁGICOS}

Cuando en 1949Alejo Carpentier prologue su novela El reino de este mundo echará a andar desde el Caribe y hacia el resto de América Latina uno de los nodos conceptuales primarios para pensar la categoría de realismo mágico, nos referimos, claro está, a la noción de "lo real maravilloso". Carpentier publica sus ideas en un artículo periodístico un año antes, 1948, en El Nacional, periódico de Caracas, en un ensayo titulado "Lo real maravilloso" y que el año entrante será reproducido como prólogo de El reino de este mundo, novela donde se narra la historia de Haití. Carpentier considera que el ámbito latinoamericano es el espacio propicio en el que la maravilla surge espontáneamente entre los habitantes de América, asumiendo una visión ontologizada de la cuestión. Al mismo tiempo, Arturo Uslar Pietri en Letras y hombres de Venezuela (1948)tras haber viajado y compartido experiencias con Miguel Ángel Asturias desde la década del '30- teoriza y nomina "realismo mágico" a ese modo diferente de percepción y concepción de un referente que se distingue del característico europeo. El escritor venezolano importa el término desde París por su amistad con Massimo Bontempelli, el pintor italiano, y se convierte así en el "primer conector" del término europeo en el campo latinoamericano ${ }^{13}$.Lo llamativo es que Uslar Pietri adopta el término por no encontrar otro mejor y así lo explicita en Godos, insurgentes y visionarios: "Lo que vino a predominar [...] y a marcar su huella de una manera perdurable fue la consideración del hombre como misterio en medio de los datos realistas. Una adivinación poética o una negación poética de la realidad. Lo que, a falta de otra palabra, podría llamarse un realismo mágico". De hecho el crítico y escritorvenezolano no se conforma solo con arriesgar una denominación, sino que fundamenta su elección en la negación de una mirada extranjerizante $y$, curiosamente, diferencia de esta manera una estética -el realismo mágico-de otra colindante -el fantástico:

\footnotetext{
Si uno lee, con ojos europeos, una novela de Asturias o de Carpentier, puede creer que se trata de una visión artificial o de una anomalía desconcertante y nada familiar... El mundo criollo está lleno de magia en el sentido de lo inhabitual y lo extraño. La mejor literatura de América Latina no ha hecho otra cosa que presentar y expresar el sentido mágico de una realidad única. (Uslar Pietri, 1986, p. 79 , destacado nuestro) $)^{14}$.
}

13 Asílo afirma Seymour Menton en su libro de 1998, ahora sabemos, desde 2009, que Onetti, y por supuesto también Payró, al menos, conocieron y acusaron recibo del concepto de Franz Roh en 1937.

14 "Realismo mágico" en Godos, insurgentes y visionarios. Barcelona: Seix barral, 1986. Las ideas originales de estos artículos están recogidas en Letras y hombres de Venezuela. México: FCE, 1948. 
El primer tramo de la cita se encarga de diferenciar -y a su manera de descalificar-en forma expresa el surrealismo europeo ("una visión artificial") y el fantástico ("una anomalía desconcertante y nada familiar") de la nueva estética local. "Mundo criollo", anota Uslar, asumiendo que el mestizaje cultural propio del Caribe y de América latina es el caldo de cultivo de esta nueva forma estilística, el "realismo mágico", superadora del estancado surrealismo europeo, capaz de dar cuenta de la cosmovisión autóctona hasta el momento inexpresada. Paradójicamente, esta designación de "sentido mágico de una realidad única" retoma la primigenia apreciación del crítico de arte Franz Roh, como ya repasamos, para caracterizar a la producción pictórica posterior al expresionismo alemán. De igual manera, Roh nos advertía-dos décadas antes de que lo hiciera Uslar Pietri- acerca de la significación del título de su volumen y su dificultad para dar con una palabra adecuada. El realismo mágico latinoamericano, acaso la categoría o taxonomía crítica más emblemática de la literatura latinoamericana, debe entonces su origen a un doble desacertado devenir -no solo se la reconoce como un sucedáneo, algo utilizado a falta de otro algo más preciso, sino que Uslar Pietri reproduce y reedita la indecisión del historiador del arte alemán. En el más puro modismo americano el tópico extranjero es fagocitado para resultar en sustancia propia -pensemos en la "antropofagia" del modernismo brasilero, importando las técnicas europeas para moldear el sustrato tupí guaraní en conceptos de Oswald de Andrade en su Manifesto Antropófago de 1928-,y, tras la consagración del Boom de la novela latinoamericana, instaurarse como una estética irrevocable para referenciar uno de los períodos más prolíficos de la narrativa latinoamericana ${ }^{15}$.

\section{LA DERIVA CRIITICA O LA CRIITICA A LA DERIVA}

Tal como lo describe Menton en su abultada cronología, a esta altura, la categoría crítica literaria en su acepción latinoamericana se encuentra desasida por completo de su original pictórica europea. No resulta innecesario repasaren el periplo temporal el devenir crítico del término: En 1955 el artículo de Ángel Flores, "Magic Realism in Spanish American Fiction"-que no menciona a Roh en ningún momento-, inscribe el término a nivel crítico latinoamericano ${ }^{16}$, sin embargo, para Menton, debido al gran abanico de autores seleccionados como representativos de la categoría se aleja de lo que Roh estipula como características precisas de esta estética. Flores señala como punto de partida

15 Para la profundización de estas cuestiones relativas al realismo mágico y su devenir como categoría remitimos a "realismo mágico:temprana recepción yúltimas consideraciones" (Linares, 2011), disponibleen http://blogs.ffyh. unc.edu.ar/centenariojoselezamalima/files/2010/02/maximiliano-linares.pdf.

16 Cuando decimos a nivel crítico latinoamericano no nos referimos a la estricta espacialidad geográfica, nótese que el artículo fue escrito en inglés y publicado en la revista Hispania, publicación española de historia. Flores, catedrático de literatura latinoamericana en el Queens College de Nueva York, da lectura a su paper en el congreso de la Modern Language Association en diciembre de 1954. Es decir, incorpora la categoría crítica a nivel de los estudios literarios latinoamericanos, incluidas las academias europeas y norteamericanas. 
la publicación de la Historia universal de la infamia (1935), primera colección de cuentos de Borges, y al igual que Menton posiciona a Borges entre los mágicorrealistas. ${ }^{17}$ Un año después, en 1956, Enrique Anderson Imbert categoriza al cuento de Arturo Uslar Pietri, "La lluvia", como perteneciente al realismo mágico, y se convierte en el primer crítico literario latinoamericano que reconoce y cita el término creado por Franz Roh. Luego, en 1967, Luis Leal rechaza la interpretación de Ángel Flores por demasiado amplia y refuta la incorporación de Borges y Kafka como los precursores del género, ya que considera que ambos pertenecen a la literatura fantástica. Leal circunscribe el realismo mágico a los autores que tratan de "descubrir lo que hay de misterioso en las cosas, en la vida, en las 'acciones humanas', [en las cuales] los acontecimientos clave no tienen una explicación lógica o psicológica" (citado por Menton, 1998, p. 227). Ya en 1974, Roberto González Echevarría realiza un racconto exhaustivo de todos los artículos de crítica literaria sobre el realismo mágico en Latinoamérica y prologa la reedición de El reino de este mundo. El crítico ejerce el sesgo a favor de la interpretación americanista de la categoría por sobre la interpretación internacionalista. Enrique Anderson Imbert insiste en tomar en cuenta el concepto en el sentido original de Franz Roh. Arribamos a 1980, cuando, Irlemar Chiampi publica O realismo maravilloso. Forma e ideologia no romance hispanoamericano, traducido como El realismo maravilloso. Forma e ideología en la novela hispanoamericana. (Caracas: Monte Ávila, 1983). La autora compendia en el término "realismo maravilloso" lo que considera potable de las categorías de "lo real maravilloso" y del "realismo mágico" tal como fueron teorizadas por la crítica literaria hasta la fecha, para finalmente diferenciarlo tanto del género maravilloso como del fantástico.

Hasta aquíla cronología, que nos arroja en el inteligente análisis de Chiampi, con quien repasaremos el modo operativo de estas últimas categorías: siguiendo a Todorov (1980) Chiampi identifica el acaecer de lo fantástico en el "efecto de vacilación" del lector "entre una explicación racional de los hechos narrados (el fantasma como alucinación, por ejemplo) y una explicación sobrenatural (los fantasmas existen)" (Chiampi, 1983, p. 82); en cambio, en el realismo mágico, o "realismo maravilloso" para ella, se produce el "efecto de encantamiento" en el receptor, los sucesos "no son dudosos en cuanto al universo de sentido a que pertenecen -es decir, poseen probabilidad interna, tienen causalidad en el propio ámbito de la diégesis y no apelan, por lo tanto, a cualquier actividad de desciframiento por parte del receptor" (Chiampi, p. 86). En lo relativo al registro maravilloso puro la diferenciación con el realista maravilloso está dada por sus respectivas adscripciones al orden de lo tético o no tético en la representación: si en el primerola causalidad delos acontecimientos

17 Menton convierte a Borges en mágicorrealista y lo deslinda del fantástico por el hecho de que no se produzcan apariciones de índole sobrenatural en sus tramas sino que todo tenga una explicación lógico-deductiva, o "imaginación razonada”, presumimos, en palabras del prólogo de Borges a La invención de Morel (1940), novela de Adolfo Bioy Casares. No coincidimos en absoluto con estas apreciaciones: ni de Flores, ni de Menton. 
insólitos está ausente por completo, ya que en los relatos maravillosos "no existe lo imposible, ni el escándalo de la razón” porque todo sucede fuera de los realia; en el segundo caso el núcleo irreductible consiste en la no disyunción de los órdenes, los actos del orden sobrenatural son naturalizados sin ninguna incomodidad por personajes y narradores, los mirabilia se convierten en naturalia, y viceversa. Por último, debemos considerar el catálogo de motivos comunes a todos estos registros descriptos por Chiampi: "apariciones, demonios, metamorfosis, alteraciones en la causalidad, el espacio y el tiempo" (1983, p. 80). De manera clara, tanto en lo que respecta a los buscados efectos de lectura por este realismo mágico y por el fantástico, como en lo concerniente a sus elecciones temáticas o argumentales, concluimos que la poética de Juan Carlos Onetti no abreva en absoluto en los dominios de estas elecciones estéticas.

A los fines de nuestro análisis principal, en este último apartado, hemos repasado, de modo sucinto, los conceptos de fantástico y de realismo mágico (en su acepción crítica latinoamericana) para poder comprender un doble movimiento por parte de la poética de Onetti: 1 . Un primer desplazamiento que resulta contemporáneo a la escritura de su epistolario: Onetti explora un camino diferenciador de la dominante estética realista- regionalista representada por la "novela de la tierra": en la búsqueda de esta novedosa vía resuelve rechazar el "fantástico rioplatense" que ya, a partir de $1940^{18}$, representa una elegante, atractiva y legítima salida al problema del Realismo; 2 . En el momento en que se produce, consideramos, la cristalización de la estética onettiana -esto es en 1950 con la publicación de La vida breve- aparece de manera simultánea en la narrativa latinoamericana el incipiente "realismo mágico". Una vez más la decisión conceptual es abordada sin reparos: continuar incólume en el trazado autoprescripto hasta lograr la consumación de una poética que, por el momento, solo podemos definir por negatividad: ni fantásticos, ni realismos mágicos, o por solipsismo tautológico: onettiana.Así como existe, sin dar lugar a dudas por la impronta personalísima de sus autores, lo kafkiano o lo borgiano, se yergue, inconfundible, lo onettiano.

18 En este año se publica la Antología de la literatura fantástica, que ya mencionamos, y Borges prologa la novela de Bioy Casares La invención de Morel. Ambos textos se consideran fundantes del fantástico rioplatense. 


\section{REFERENCIAS}

Chiampi, Irlemar. (1983). El realismo maravilloso. Forma e ideología en la novela hispanoamericana. Caracas: Monte Ávila.

Concha, Jaime. (1980). “Onetti o una fantasía sedentaria”, Texto Crítico (Xapala), vol 6.

Díaz, José Pedro. (1986). El espectáculo imaginario: Juan Carlos Onetti y Felisberto Hernández, ¿una propuesta generacional? Montevideo: Arca.

Montevideo: Arca.

(1987). Juan Carlos Onetti: el espectáculo imaginario, II.

Flores, Ángel. (1955). “Magic Realism in Spanish American Fiction”. Hispania. XXXVIII, 2.

González Echevarría, Roberto. (1974). "Isla a su vuelo fugitiva: Carpentier y el realismo mágico”. Revista Iberoamericana: N 86, feb.mar 1974, p. 9-63.

Harss, Luis. (1966). “Juan Carlos Onetti o las sombras en la pared”, Los nuestros. Buenos Aires: Sudamericana.

Jardí, Enric. (1987). Torres García. Barcelona: Polígrama.

Menton, Seymour. (1998). Historia verdadera del realismo mágico. México: FCE.

Pollastri, Laura. (2013). “La opinión del espejo: ficción e imagen en la escritura de JCO”, en Onettifuera de sí. Teresa Basile y Enrique Foffani (eds.) La Plata: Katatay.

Todorov, T. (1980). Introducción a la literatura fantástica. Buenos Aires: Eudeba.

Verani, Hugo. (2009a.). Onetti: El ritual de la impostura. Segunda edición, corregida, actualizada y ampliada. Montevideo: Trilce.

(2009b.). “Cartas de un joven escritor”, estudio introductorio a Juan Carlos Onetti. Cartas de un joven escritor. Correspondencia con Julio E. Payró. Montevideo: Trilce.

-(2009). “Onetti y la pintura”.

(2012). “Una poética de la ficción: Onetti, la pintura y algo más", Presencia de Juan Carlos Onetti en su centenario (1909-2009). Ed. Rose Corral. México: El Colegio de México. 


\section{FUENTES}

Bioy Casares, Adolfo. (1940) "Prólogo" en Antología de la literatura fantástica. J. L. Borges, Silvina Ocampo y A. Bioy Casares, antólogos. Buenos Aires: Sur.

Borges, Jorge Luis: "Prólogo" a La invención de Morel. De Adolfo Bioy Casares: (1972) Madrid: Alianza.

Carpentier, Alejo. (1967) Tientos y diferencias. Montevideo: Arca.

Onetti, Juan Carlos. (2009) Cartas de un joven escritor: Correspondencia con Julio E. Payró, Edición crítica, estudio preliminar y notas de Hugo J. Verani. Montevideo/ México/Santiago/Rosario: Trilce, Era, Lom, Beatriz Viterbo. (2009) Novelas cortas: Edición crítica. Edición de Daniel Balderston, Liminar de Juan José Saer. Colección Archivos 59, Córdoba, Arg.: Alción Editorial/CRIA/Biblioteca Nacional de Uruguay.

Obras completas. Edición de Hortensia Campanella. Barcelona: Galaxia Guitenberg/ Círculo de Lectores, tres volúmenes.

Vol. I: (2005). Novelas I (1939-1954), Preámbulo de Dolly Onetti. Prólogo de Juan Villoro.

Vol. II: (2007) Novelas II, (1959-1993). Prólogo de José Manuel Caballero BonaldPostfacio de Liliana Díaz Mindurry.

Vol. III: (2009) Cuentos, artículos y misceláneas. Prólogo de Pablo Rocca.

Roh, Franz.(1927) Realismo mágico. Post-expresionismo. Problemas delapinturaeuropea más reciente. Traducción de Fernando Vela. [Nach- Expressionismus, magischer Realismus. Probleme der neuesten europaischen Malerei. Leipzig: Klinkhardt y Biermann, 1925.] Madrid: Revista de Occidente.

Uslar Pietri, Arturo: "Realismo mágico" en Godos, insurgentes y visionarios. Barcelona: Seix Barral. 